\title{
Designing a Teacher's Handbook: Perspectives of Pre-Service Elementary Teachers Regarding Activities and Songs
}

\author{
Oguzhan Atabek ${ }^{1} \&$ Sabahat Burak ${ }^{1}$ \\ ${ }^{1}$ Faculty of Education, Akdeniz University, Antalya, Turkey \\ Correspondence: Oguzhan Atabek, Department of Computer Education and Instructional Technology, Faculty of \\ Education, Akdeniz University, Dumlupinar Boulevard, Campus, 07058, Antalya, Turkey.
}

Received: July 21, 2019

Accepted: September 2, 2019

Online Published: October 25, 2019

doi:10.5539/ies.v12n11p67

URL: https://doi.org/10.5539/ies.v12n11p67

\begin{abstract}
Printed educational materials such as teacher's handbook may affect the quality of education as much as teachers, curriculum, educational environment, and the other course materials. Perspectives of eighty-two pre-service elementary teachers regarding the activities and songs included in the teacher's handbook for music course were examined by content analysis for shedding light on the nature of the handbook and for producing knowledge about how an effective teacher's handbook for music course may be like. Even though the question was deliberately worded to let respondents express their both positive and negative views, the number of respondents who expressed positive views and the frequency of such expressions were considerably lower compared to the negative ones. Inappropriateness for age group and learning outcomes, insufficiency for facilitating learning, requiring hard-to-attain materials, and difficulty of application raised as major concerns for both activates and songs. Additionally, activities were argued to be repetitive and lacking entertainment while songs were criticized for their rhythm, melody, lyrics, quality, and practicability in the classroom.
\end{abstract}

Keywords: teacher's handbook, instructional material, elementary music education, instructional activity, song

\section{Introduction}

Authentic materials such as printed resources used in the lesson may affect the quality of education as much as teachers, curriculum, educational environment, and the other course materials (Al Azri \& Al-Rashdi, 2014; Chang \& Ley, 2006; Jacobson, Degener, \& Purcell-Gates, 2003). It has been reported that students prefer printed materials to electronic alternatives, as well (Annand, 2008; Spencer, 2006; Woody, Daniel, \& Baker, 2010). Since learning can be impacted by the format of the medium through which the text is consumed (Morineau, Blanche, Tobin, \& Guéguen, 2005; Rockinson-Szapkiw, Courduff, Carter, \& Bennett, 2013) printed materials are crucial for instruction. Therefore, printed educational texts such as the student's course book and teacher's handbook (TH) should be rigorous and effective. Hartley (2013) states that "instructional text is usually more complex in its structure and appearance than is continuous prose $[\ldots]$ and thus it requires greater thought about its presentation" (p. 9). He argues that, regarding printed instructional text, planning can help the non-specialist individuals who are involved in the publishing of such printed materials to be more effective. Reading a book is a dialogical activity involving consciousness of both the writer and the reader and a dialogue between them (Wright, McCarthy, \& Meekison, 2003, p. 45). However, it is argued that textbooks are filled with facts that students are expected to memorize (Bransford, 2000) while practical knowledge is more than a list of facts. In the minds of learned individuals, knowledge is contextualized, connected, and organized. A printed instructional text such as a handbook should provide the readers with ways for contextualizing the content while also helping the teacher to provide his or her own students with such content.

One of the resources used by music teachers in Turkey is the THs for elementary and secondary music courses. Handbook is described in the Oxford Dictionary as "a book giving information such as facts on a particular subject or instructions for operating a machine" (Handbook, 2018). Cambridge Dictionary describes it as "a book that contains instructions or advice about how to do something or the most important and useful information about a subject" (Handbook, 2018). Moreover, European Commission (n.d.) states that TH "serves as a methodology for the practical use of the many teaching and learning activities" (p. 5). Although handbooks are perceived as rather "dry, stiff, and boring", these books may be a route map showing people how to work in an institutional order (Christensen, 2015). Turkish Ministry of National Education Textbooks and Education Tools Regulation (2012) 
describes TH as "a printed/PDF work, prepared for teachers to benefit from, which will ensure the effective use of the textbook of the course in accordance with the learning outcomes and clarifications included in the related curriculums and encompasses various examples, exercise, URLs related with the unit, reading resources, and other activities".

How teachers use handbooks and their effects on students' success is related to the preparation of the handbook and its quality. Christensen (2015) has stated that a successful handbook should be prepared in an innovative way. He argued that having a readable, attractive, colorful and eye-pleasing design and including interactive content and quizzes would contribute to the effectiveness of the handbook. Additionally, handbooks are useful means for the orientation of the beginning teachers (Pierangeli, 2006). Handbooks can be used as an effective educational instrument for educators (1) to convey the information, they need both to teach and to evaluate their skills, to the candidates; (2) to provide the consistency of the information conveyed and (3) to teach them how to be more effective educators (Pierangeli, 2006). Thus, an effective and functional teacher's handbook for the music course (THMC) may contribute significantly to the teaching and learning processes and therefore, may increase the success in the music courses. In this context, previous research on THMC emphasized the positive and negative aspects of the content (Bulut, 2012, 2014, 2015; Demirci \& Albuz, 2010).

\subsection{Music Education in Turkey}

Although it has problems, limitations, and inadequacies related to the application of the content, in Turkey, the music course is taught by using the THMC. In Turkey, elementary school music curriculum has constantly been changed since 1923. It has been once again overhauled in 2006, this time in accordance with the constructivist approach. The Ministry of National Education put that "constructivist" program, which is still in effect, into force in 2007-2008 school year (Bulut, 2012). Elementary education music curriculum of 2006 was formed based on four learning domains: Listening-singing-playing, Musical Perception and Acquisition of Knowledge, Musical Creativity, and Music Culture. Ministry officials preparing the curriculum tried to determine the learning outcomes to be congruent with learning domains. In Turkey, primary education consists of two stages: elementary $\left(1^{\text {st }}\right.$ to $4^{\text {th }}$ grades) and middle school $\left(5^{\text {th }}\right.$ to $8^{\text {th }}$ grades $)$. Music is a compulsory course in both stages. Secondary education is provided in high schools $\left(9^{\text {th }}\right.$ to $12^{\text {th }}$ grades $)$ in which music is an elective course. In both primary and secondary education, music course is taught one hour a week (Ministry of National Education, 2006).

\subsection{Structure of the THMC}

For elementary school, Ministry of National Education published two books of which one is for grades 1, 2, and 3 (Yaşar, 2016) and the other is for grades 4 and 5 (Yaşar, Çelik, \& Şendağ, 2016). Information regarding music curriculum, theories and methods used in music education, principles to be obeyed while teaching music, evaluation methods, and introductory information regarding the book is provided before the first section of the THs. An annual plan-one for each year-is provided in the next sections. In the following sections of the book, separately for each grade, the THMC is divided into topics. Learning domains, related learning outcome, associating with the other lessons, duration, materials, learning-teaching process, assessment and evaluation issues, and explanatory information are included for each topic.

In the "learning-teaching process" section, the instructions for teachers are provided. In this section, two sub-sections are included: activities and songs. In the activities sub-section; rhythms, rhymes, theoretical information, and music games are provided with information on how these component should be taught as well as how they should be implemented as educational activities. In the songs sub-section, the lyrics and musical notes of the songs that are aimed to be taught in the lesson are provided. The scope of this paper is limited with the activities and songs that are provided in the learning-teaching section of the THMC.

The songs included in the music education in Turkey are divided into 4 categories: lyrically adapted, tonally formulated, anonymous and Turkish school songs (Alkar, 2008; Özgül, 2009). Lyrically adapted songs are the songs with a foreign tune for which Turkish lyrics are written. The tunes of these songs are selected among the folk music and school music tunes of the European societies. Tonally formulated songs are the ones that are composed by Turkish school music composers in accordance with the tonal structure of Western music. Sağer (2002) states that they are "made by the Turkish composers within the major-minor gamut and scales of the western music, by imitating the sense of aesthetics and admiration of the western societies but which are unfamiliar with their structure and self" (p. 8). Anonymous songs are extensions of folklore that have generally been revealed through compilation or transmitted through oral tradition. Turkish school songs are the artworks made by the Turkish school music composers and rely on Turkish folk music. Özgül (2009) argues that school songs are "authentic creations which are made within the Turkish music gamut and scales and suitable to the taste of the public" (p. 27). He argues that they take their structure and core from the folk music and are not tonally formulated, pretentious, or 
unfamiliar to the public. Songs within aforementioned four categories are included in each topic and learning outcome in the THMC. Activities in the THMC include: (1) tasks of the teacher; (2) behaviors and skills that will be expected by teachers from their students; (3) music games, and applications related to the learning outcomes. The purpose of the activities is to facilitate active participation of the students and provide opportunity for learning by doing.

\subsection{Significance and Purpose}

In Turkey, music course is taught by elementary generalist teachers from $1^{\text {st }}$ to $4^{\text {th }}$ grades. Elementary teachers believe in the significance and necessity of music education, however, most of them find themselves incompetent for teaching music (Bresler, 1993; Kocabaş, 2000; Küçüköncü, 2000; Mills, 1989; Şahin \& Aksüt, 2002; Yünlü \& Sağlam, 2004). A handbook which will support and guide elementary teachers in teaching music may facilitate their work while increasing their interest in, desire for, and attitude towards the course consequently giving way to increasing the success of students. This study focuses on the activities and songs sub-sections included in the elementary school THMC for $1^{\text {st }}$ to $4^{\text {th }}$ grades. The reason why these two topics were included in the study is that they constitute the very heart of the course and are directly related to the learning process. Additionally, the songs taught in the elementary school form the basis of the music education provided in this period. On the other hand, activities used in the elementary music course require teachers to be competent in method and practicing. Elementary teachers should have the skills to evaluate the quality of the songs and activities in the handbook, as well.

There are no studies specifically aimed at investigating activities and songs in the THs but research on other aspects of TH have been reported (Aykaç, 2007; Ayvacı \& Çoruhlu, 2011; Demirci \& Albuz, 2010; Göçer \& Aktürk, 2015; Şahin, 2008). Research literatures on THs are remarkably limited especially considering research literature published in English. Investigating pre-service teachers' opinions on the activities and songs included in the TH may shed light on their future teaching performance and competency while also contributing to scientific understanding about handbooks. Moreover, Turkey lowered the school starting age from seven to five while also decreasing the period of study for elementary school from five to four. Instructional designers did not design those already existing handbooks for current age groups. Hence, handbooks may need improvement or complete redesign while elementary schools are a new playground for instructional designers. Additionally, while teachers will begin to use the book directly in line with the orders from the ministry without in-depth analysis and reflection, prospective teachers will have the opportunity to examine the book closely in their classes and evaluate the book as part of their lessons. Therefore, perspectives of pre-service elementary teachers may contribute to possible improvements to the THMC giving way to increasing its effectiveness. Therefore, the purpose of this research is to examine the perspectives of pre-service elementary teachers regarding the activities and songs included in teacher's handbook for music course in order to (1) shed light on the nature of current teacher's handbook for music course, and (2) produce knowledge about how an effective teacher's handbook for music course should be like.

\section{Method}

The study was designed as a case study employing qualitative content analysis. An interpretive approach was utilized by using inductive coding. Fraenkel and Wallen (2000) define content analysis as "a technique that enables researchers to study human behavior in an indirect way, through an analysis of their communications" (p. 469). They argue that content analysis technique has wide applicability in educational research and can be used to (a) understand organizational patterns by examining printed material prepared by educational administrators, (b) gain a sense of how teachers feel about their work by examining what they have written about their job, (c) give researchers insights into problems for investigating in future research, and (d) help educators plan better instructional activities by analysis of instructional material and tasks given to students by their teachers (pp. 471-472). Moreover, they state that content analysis is an advantageous method for analyzing educational books or a new curriculum as well as students' and teachers' thoughts and feelings about them (p. 473). Since the purpose of the research was to examine the thoughts and feelings of pre-service teachers regarding the activities and songs included in the TH in order to shed light on the nature of current THMC, and produce knowledge about how an effective THMC should be like, content analysis was chosen as the method of the research.

\subsection{Participants}

Eighty-two pre-service teachers participated in the study. The sample of participants was a convenience sample. All the participants were sophomores enrolled in the elementary education BSc program of faculty of education at a public university in Turkey. Students taking the "Music Teaching" course were invited in the study and all of the students agreed to participate $(\mathrm{N}=82$, response rate $=100 \%)$. Prior to the semester that the research was conducted, 
all participants had also taken a 3 hours "Music" course which lasted for 16 weeks. Hence, Music Teaching course was their second course about music. Both courses are standard parts of participants' curriculum. The Music course encompasses acquiring basic musical knowledge; acquiring hearing, reading and listening skills for music; becoming well acquainted with primary school repertoire; gaining competence in singing primary school repertoire; and learning to play recorder. The Music Teaching which is a 3 hours course encompasses microteaching activities about teaching music in elementary schools. Of 82 sophomores, 55 (67.1\%) were female and $27(32.9 \%)$ were male. Ages of the participants ranged from 18 to 23 with a mean of 20.54 and a standard deviation of 0.971 .

\subsection{Data Collection}

Data was collected by a questionnaire consisting of two open-ended questions: (1) "What are your positive and negative opinions about activities in teacher's handbook for music course?" and (2) "Please reflect on the songs in teacher's handbook for music course regarding melody, rhythm, lyrics, and appropriateness for the level". The questionnaire was prepared in Turkish. Pre-service teachers responded the questions in Turkish, as well. However, responses of the pre-service teachers, which were quoted in this paper, were translated into English for the audience.

Since the purpose of the research was to uncover what the participants personally think and feel about the THMC and its application, written responses to open ended questions of a questionnaire were determined as the data of the research. Fraenkel and Wallen (2000) state that students' written responses to an open-ended questionnaire is an appropriate source of data for content analysis (p. 473). Prior (2003) argues that written text communicates what the author assumed were facts. Charmaz (2006) states that elicited texts such as written responses to open ended questions may elicit thoughts, feelings, and concerns of the participants. She argues that elicited texts such as written responses to open ended questions "can foster frank disclosures that participants might not wish to make to an interviewer" such as revealing secrets that risk shame, disgrace or failure (p. 36). It should be noted that participants used the THMC in their lessons that were part of their teacher training. When they become in-service teachers in the future, they will also use those THs while teaching. Hence, revealing personal evaluation of such a material may risk shame by association with trouble at work or personal failure. In addition to that, since discussing official textbooks of the government is a political subject in Turkey, anonymous elicited text in the form of written responses to open ended questions was considered more appropriate data source for this research. Moreover, in a similar vein, Fraenkel and Wallen (2000) argue that through analysis of textbooks and written communication, information that might be difficult to obtain can be gained unobtrusively by content analysis without the authorities being aware that such data is being investigated (p. 480).

\subsection{Procedure}

As part of their education in the teacher-training program, the participants attended the Music Teaching course in the classroom. Throughout the semester, over a period of 12 weeks, the participants attended the 3-hour Music Teaching lesson each week. The handbook includes various topics for different grades. Every topic includes related activities and songs. A particular topic was assigned to each participant. Participants were required to apply the activities for the other pre-service teachers and to teach the songs correctly. While one of the pre-service teacher was applying the activities and teaching the songs in the role of teacher, all other pre-service teachers participated as students and were asked to read and look through the handbook. At the end of the semester, after application of all of the activities and teaching of the songs, the instrument was administered. The students were given a choice about participating in the research. Instructor of the course did not know which questionnaire belonged to which student.

\subsection{Data Analysis}

Initially, all papers were screened to exclude the ones which was not completed or were filled with irrelevant answers. Then, responses to open-ended questions were analyzed by qualitative content analysis using an interpretive and inductive approach. The focus on meaning is a fundamental aspect of qualitative research and it is central to interpretive approach (Maxwell, 2013). While conducting the analysis, latent content was coded in contrast to manifest content. Coding latent content of a communication has the "advantage of getting at the underlying meaning of what is written" (Fraenkel \& Wallen, 2000, p. 476). Hence, interpretive approach was suitable with the purpose of the research. On the other hand, through inductive approach, the categories and themes were built from bottom up by organizing data into increasingly more abstract units of information (Creswell, 2013). Inductive reasoning tries to find binding principles in data in order to construct generalizations, relationships and theories (Gray, 2009). Inductive approach requires open mindedness to ensure that data are not ignored (McGhee, Marland, \& Atkinson, 2007). 
During the analysis, the researcher initially employed open coding. Open coding was performed first by breaking the data down into segments such as words, phrases, or sentences. Then, those parts were labeled with a name. Those names constituted the codes of the analysis. After finishing coding process for all of the responses, codes were translated into concepts and finally concepts into categories. Coding latent content rather than manifest content was aimed for increasing validity. For checking reliability, the data were analyzed independently by two researchers who are the authors of this study. Percentage of agreement was computed by dividing the number of instances of agreement by the total number of instances and multiplying the quotient by 100. Consistency of categorization was $92 \%$ agreement between the researchers. Until 100\% agreement was reached, all disagreements were resolved by discussion.

\section{Results}

Content analysis resulted with seven categories for activities and three categories for songs. Categories for the activities sub-section were Appropriateness, Sufficiency, Learning, Material, Difficulty, Entertainment, and Repetition in descending order of significance. Categories for the songs sub-section were Rhythm, Melody and Lyrics, Teachability, and Quality of the Songs, in descending order of significance.

Some of the pre-service elementary teachers argued that activities provided in the learning-teaching section of the THMC are not sufficient enough for facilitating Learning in music courses. Additionally, they seem to be not appropriate for the classroom practice, age group, grade level, or learning outcomes. Moreover, some pre-service teachers are concerned that instructional Materials already provided for music course in standard classrooms are not adequate for THMC for it to be used effectively. Hence, THMC constitute a Difficulty for the teacher for creating a learning environment rich with Entertainment that is required for motivation, engagement, and learning. On the other hand, some of the pre-service elementary teachers argued that songs provided in the learning-teaching section of the THMC fails short for facilitating learning because of the low Quality of the Songs. In addition, songs were not believed to be appropriate for student level, age group, and learning outcomes. Songs were also considered to be insufficient regarding their Rhythm, Melody, Lyrics and notes. Finally, together with aforementioned issues, incompatibility between THMC and instructional materials already provided for music course in the classrooms decrease the Teachability of the songs in the classrooms. Findings are detailed in the following sections. In the quotations, $\mathrm{F}$ stands for Female while $\mathrm{M}$ stands for Male. Accompanying number is the age of the participant.

\subsection{Results Regarding Activities in the THMC}

Pre-service teachers reflected on the activities sub-section in the THMC in seven categories: Appropriateness, Sufficiency, Learning, Material, Difficulty, Entertainment, and Repetition.

\subsubsection{Appropriateness}

Pre-service teachers were particularly interested in the appropriateness of the activities. Some of them stated that while activities were appropriate for students' grade levels, they were not appropriate for the age group. For explaining why they found the activities as inappropriate, pre-service teachers propounded as being boring, not sounding nice, or being simple as shown below:

"The activities are inappropriate for the students' age group, they are hard to understand and they are boring." (F, 20).

"I think the activities are not appropriate for the children, the rhythms in some of the songs do not sound nice." (F, 21)

"The activities are sometimes inadequate for the age of the children and some of the activities are tiring for them. Some of the activities are nonsense and some of them affect the physical movements of the children." (F, 21)

Additionally, some of the pre-service teachers stated negative opinions about the consistency and appropriateness of the activities regarding learning outcomes and noted that this inconsistency harmed the plausibility of the book.

"I think that the activities are not in coherence with the learning outcomes. In addition, the activities are not sufficient for the students." (F, 20)

"Some of the activities are definitely not appropriate for the learning outcome that is desired to be provided and they have negative characteristics in terms of practicability" $(F, 19)$

Some of the pre-service teachers voiced their concerns regarding the practicability of the activities in the classroom. They generally had negative opinions on this matter. These opinions coincided with the opinions stated in the materials category. They were concerned about the lack of sufficient educational materials required while 
using the THMC for in-class applications giving way to a decrease in perceived practicability.

"The activities are fine but they cannot be applied in a very crowded classroom." $(F, 21)$

"As it is not possible to apply some of the activities for the whole class, they cause a negative effect for us." $(M, 20)$

"In order to carry out the activities, the materials for the activities should be easily available in every environment." (M, 21)

"Without a pc, classroom projector etc., it is impossible to apply the activities. In this case, the teacher should have a good grasp of the activities and songs." (M, 20)

\subsubsection{Sufficiency}

Pre-service teachers put emphasis on the sufficiency when reflecting on the THMC. Generally, the pre-service teachers presented negative opinions about the efficiency of the activities. Some of the pre-service teachers who commented on the sufficiency of the activities did not mention why exactly found the activities sufficient or insufficient. They preferred to reply just with a short answer: sufficient or insufficient. Those pre-service teachers may not have required knowledge or qualification to evaluate the sufficiency of the activities. Honesty of the participants contributed to the reliability of the analysis. On the other hand, some of the pre-service teachers questioned the sufficiency of the activities in a more detailed manner. They stated that the activities did not cover the course subject completely and found the activities insufficient in terms of content.

"I think it would be better if there were more music education for children. The activities can be changed, they may be different." (M, 21).

"In some of the parts, the activities include the course and in some of them they are insufficient." (F, 23).

"The activities were insufficient, the music and rhythms were insufficient. Livelier, different activities and music may be used." (F, 20).

In parallel with the findings of Bulut $(2014,2015)$, some of the pre-service teachers mentioned an inconsistency of the activities with the learning outcomes in the THMC. Regarding comprehending the topic sufficiently, for some of the learning outcomes, they found the number of activities inadequate.

"There were good activities. But there were not activities in all topics on an equal basis. The number of the activities was insufficient in some topics. " $(F, 20)$

\subsubsection{Material}

Some of the pre-service teachers commented on the several must-have instructional materials that are required for applying activities. They also argued that some of the required materials are impossible to access regarding standard classroom conditions. Concerns over required materials may stem from the feeling of inadequacy in teaching music and hence from the need for sharing the burden of teaching with technology. Pre-service teachers stated that the conditions of the country should be taken into consideration while designing handbooks:

"Some activities may be difficult for the teachers in terms of finding the related materials." (F, 21)

"I think the activities are quite appropriate for conveying the learning outcomes. But the lack of equipment in some places will affect the practicability of these activities." (M, 20)

"It may be difficult for every student or school to obtain the rhythm instruments that are required to be used in some activities." (F, 19)

Some of the pre-service teachers also commented on the comprehensibility of the explanations and instructions in the THMC about the exercises. The issue with the comprehensibility of the material is dealt with in the following Difficulty category.

\subsubsection{Difficulty}

Some of the activities were found to be difficult for the teachers or for the students. The incompetence of the teachers may further elevate the difficulty of applying the activities. Pre-service teachers experienced the activities both as teachers and as students. They argued that the activities were not only difficult for the teacher to apply but also was difficult for the students to participate.

"I even had difficulty when I had my friends do the activities. Comparing with this class including my friends, a real class will have more difficulty in understanding the subject. $(F, 19)$ 
"I think the activities are confusing for the students." (F, 21)

Some of the pre-service teachers found the activities incomprehensible for both teachers and students, especially regarding the explanations and instructions in the THMC about the exercises:

"I think the activities are not comprehensible. I think they are generally appropriate for the learning outcomes but there are problems in terms of practicability. I think it may be stated with a clearer explanation." (M, 20)

"The negative characteristics of the book are that the instructions are not clear enough, the instructions are nonsense." $(F, 22)$

"The activities should be more clear and comprehensible (F, 20)

\subsubsection{Repetition}

Some of the pre-service teachers stated that the activities were mostly similar. They argued that activities seemed to be repetitions of each other and lacked variety and innovativeness. Repetition and monotony may have also contributed to the perception of boringness.

"Some activities seemed to have too many similarities; I think that the activities could be diversified."

$(M, 18)$

"The activities of some of the topics seemed to have many similarities. $(F, 20)$

\subsubsection{Entertainment}

Pre-service teachers consider entertaining children as one of the significant functions of music (Özmenteş, 2009). According to some of the pre-service teachers who place importance on entertainment factor, some of the activities in THMC were not entertaining and even boring. Entertainment category seems to be related with appropriateness, especially considering "entertaining children". Pre-service teachers emphasized that, in order to provide motivation for the lesson, the activities should be entertaining and interesting.

"Most of the activities are not entertaining enough to attract the students. I guess they will do it once, twice and then they will get bored." (F, 20)

"The activities may be adequate to understand the topics but they are not entertaining." (M, 20)

"The activities are fine but the frequency of the repetitions make it boring." $(F, 20)$

\subsection{Results Regarding Songs in the THMC}

The pre-service teachers reflected with longer and more statements on the songs in THMC compared to the activities. While there were 143 codes in the activities sub-section, songs sub-section yielded 175 codes. This may indicate that there may be more problems with the songs compared to the activities or they may have considered the music education more as related with songs rather than activities. On the other hand, those more intense and frequent statements clustered around fewer categories indicating the prominence of the issues. Opinions of pre-service teachers were mostly negative about the songs.

\subsubsection{Rhythm/Melody and Lyrics}

Pre-service teachers expressed generally negative opinions regarding the rhythms of the songs. The rhythms were mostly thought to be inappropriate for the students' musical competency levels. In the context of comprehensibility, rhythms seemed to be too easy or too hard according to students' level. According to pre-service teachers, inconsistency between the difficulty of rhythms and students' competency may give way to poorer rhythmic developments. It may also cause problems in perceiving rhythm and playing to the beat. Additionally, pre-service teachers emphasized that the songs were very fast or slow in term of the beat. They underlined that some of the rhythms were incomprehensible and difficult.

"Although the activities are fine the songs are difficult for some children. The rhythm is incomprehensible." (F, 21)

"I think they are a bit slow for the primary school students and I think that if we have the songs sung and animate them, it will be more effective." (M, 21)

The rhythms and melodies were not appropriate for the age group. I think there were too fast ones." (F, 20)

"The rhythm of the songs may be a bit difficult." (F, 20)

Regarding the melody of the songs, pre-service teachers mostly noted the incomprehensibility and insufficiency. 
They also were concerned about the inconsistency among the melody, rhythm and lyrics.

"The rhythms and melodies of some of the songs are not sufficient in terms of the level of the grade." $(F, 19)$

"The melodies of some of the songs could not be understood completely in the presentations. This may be caused by the person who made the presentation." $(F, 20)$

"The rhythms of some of the songs are not in accord with their melodies and lyrics." $(F, 21)$

The negativity of the opinions on the lyrics of the songs was remarkable. Pre-service teachers thought that the lyrics were insufficient, meaningless, and inappropriate for student level. In addition to the problems about the comprehension and application of the rhythms and melodies, the lyrics of the songs were stressed to be meaningless, insufficient, and even "nonsense".

"The lyrics of some of the songs are nonsense, they were like casually written." (F, 20)

"Their melodies and lyrics are very meaningless and terrible." (M, 22)

"Some inconsistencies occurred in the lyrics of some songs, in order to make them appropriate for the

level. These should be eliminated and more meaningful lyrics should be used for children." (M, 19)

"Their lyrics have no meaning, are unpleasant and do not bring anything." (F, 21)

"Sometimes the lyrics were not reasonable. They were only harmonized with the rhythm." (F, 21)

\subsubsection{Teachability}

While reflecting on the rhythm, melody, and lyrics of the songs, some of the pre-service teachers also expressed opinions about the songs in general especially regarding their teachability. Similar with activities sub-section, they discussed the appropriateness of the songs for the level and age of the students in relation to teaching in the classroom. Opinions on the application and practicability of the songs were mostly negative emphasizing the difficulty in teaching. Requiring hard-to-attain material was also highlighted.

"Some of the songs were not appropriate for the age group." (F, 20)

"The melodies and the lyrics of the songs are fine but I think that the level appropriateness is questionable in conveying them to the students." (F, 20)

"Difficult to apply. It is difficult to control the class. They do not attract the students' interest." (F, 20)

"I think that it is hard to teach and apply the songs without using the internet or other sources, it is caused by the personal incompetency." (F, 23)

"Finding some of the songs was difficult. They are not sufficient in terms of accessibility and practicability." (F, 20)

Finally, another remarkable opinion shared by some of the pre-service teachers was that the songs would not contribute to the developments of the students.

"They are not instructional enough in terms of melodies and rhythms." (F, 23)

"I think that they are simple in terms of the appropriateness for the level and simple for the development of children." ( $F, 20)$

3.2.3 Quality of the songs

Regarding the characteristics of the songs, most of the pre-service teachers thought that songs were generally simple, insufficient, and "nonsense". Songs were not thought to be attractive or entertaining, either. Curiously, even though it was "just a teacher's handbook" pre-service teachers developed negative attitudes towards the songs.

"The songs are very simple. They don't have the characteristics [required for the] children." $(M, 22)$

"Their negative part is that they are not appropriate for the level. 1st grade music was presented at 5th Grade. Their positive side is that they are plain, their melody and rhythm is enjoyable." (M, 22)

"Most of the songs are long and they require to be memorized. The application will remain mostly in the classroom." (M, 20)

"The lyrics of the songs are simple and their melodies are bad." (F, 20) 


\section{Discussion}

Elementary pre-service teachers reflected on the activities and songs sub-sections of the THMC in detail, however, their opinions were mostly negative. Even though the question was deliberately worded to let respondents express their both positive and negative views, the number of respondents who expressed positive views and the frequency of such expressions were considerably lower compared to the negative ones. Relative weight of the negative opinions indicates that current THMC may benefit from improvement and better design.

\subsection{Activities}

Initially, in order to apply the activities in the handbook, pre-service teachers were required to obtain technology and materials that were not readily available in a standard classroom. Sometimes it was hard to find and attain obligatory materials. Requiring hard-to-attain materials or educational technology increased the level of difficulty for applying the activities in the classroom setting. This result was in parallel with prior research emphasizing that physical conditions and materials in the schools are not sufficient to apply some of the activities included in the THMC (Demirci \& Albuz, 2010). Pre-service teachers needed those additional resources even during the microteaching process where they applied the activities. Thinking that the conditions of the schools where they will start teaching will not be good enough and that they will not be supported to obtain the educational materials may create anxiety in pre-service teachers. Anxiety and stress caused by required hard-to-attain materials may give way to avoiding the use the handbook and giving up applying the activities.

A considerable portion of pre-service teachers thinks that THMC should include activities that will conduce them to be more active in the lessons and contribute more to children's psychological and social development. Call of the pre-service elementary teachers who used the THMC for inclusion of learning activities, which will conduce students to be more active in the lessons, was one of the more significant findings of the study considering that THMC was designed within a "constructivist" paradigm that is renowned for attaching particular importance to learning by doing, learning by practicing, experience, and having students be active in the classroom.

In parallel with the findings from multiple research by Bulut $(2014,2015)$, some of the pre-service teachers did not find the activities to be consistent with the learning outcomes. Pre-service teachers argued that students' skills that are used for activities were different from the ones stated as the learning outcomes. Inconsistency between learning outcome and the activity may lead students to not understand the purpose of the activity. It may also reduce the persuasiveness and effectiveness of the handbook. Inconsistency regarding the number of the activities provided for each learning outcome was also highlighted. Only some of the learning outcomes were provided with sufficient number of activities. Considering pre-service teachers' call for activities that conduce students to be more active in the lessons, they may be planning to teach music courses with more activities involved. Taking the concerns about the materials into account, pre-service teachers may also be needed the opportunity for being able to select from among several activities in order to avoid being stuck with non-activity lessons because of lacking required materials. Moreover, considering pre-service teachers' perceived incompetence in teaching music (Bresler, 1993; Kocabaş, 2000; Küçüköncü, 2000; Mills, 1989; Şahin \& Aksüt, 2002; Yünlü \& Sağlam, 2004), pre-service teachers may be asking for more activities for avoiding the music lessons themselves in totality by employing the activities as tools to "fill the time" or at least as learning experiences to receive support.

Related with inconsistencies between activities and learning outcomes, activities were found to be mostly similar with each other. On the other hand, even though pre-service teachers found the activities to be appropriate for the level of students' musical competence, they expressed negative opinions about appropriateness of the activities for age group and grade level. It should be noted that repetition might further increase inappropriateness considering the unchanging nature of activities while the age and musical competence of the pupils are constantly advancing. In parallel with Christensen's view (2015), these findings indicate that one of the design principles while creating a TH should be innovativeness. An innovative design with keeping the need for variety in mind may contribute to the development of a THMC with more activity choices. Hence, among plentiful original activities, teachers may always -or at least more often- find one consistent with learning outcomes, age groups, and grade levels.

Pre-service teachers stressed that activities were difficult to apply both as students and as teachers. Part of the reason was hard-to-attain materials required by the TH. Activities' inconsistency with the learning outcomes and inappropriateness for age groups and grade levels seemed to play a role as well. TH may benefit from a design, which endorses principles of innovativeness and variety. However, pre-service teachers emphasized that the textual content was hard to comprehend. Sometimes even simple explanations were hard to understand. Therefore, it seems that in addition to innovativeness, a better handbook may benefit from message design principles in order to foster communicability of the textual "message" comprising the content. Moreover, designers should always consider the technological and material inventory of a "standard" classroom. Designers should never overlook 
learner characteristics.

\subsection{Songs}

Pre-service teachers presented more opinions on the songs compared to the activities and these opinions clustered around fewer issues. The opinions were mostly negative. Strong and prevalent negative opinions may lead to development of negative attitudes toward the songs they are expected to teach. Considering that THMC is prepared for use throughout a long period of time, negative attitudes may also develop towards the handbook or even towards the music course. What is worse, students too may develop negative attitude towards the music course in such an early age. Pre-service teachers who articulate a great deal of negative opinions experienced the TH not only as teachers but also as students. Students in elementary schools are being exposed to a learning experience created by using the TH as a blueprint. Hence, it should be noted that, what is at stake is not just the success or comfort of teachers but also students' attitude towards music course.

Pre-service teachers found the beat of the songs to be very fast or very slow. They described the rhythms as incomprehensible and difficult. Additionally, they did not find the songs appropriate for the level of children. These concerns regarding the rhythms of the songs may cause the songs to be hard to learn for children. Similar concerns were raised for the melody of the songs, as well. Perceived incomprehensibility and difficulty of the songs regarding rhythm and melody may also stem from low self-efficacy beliefs about teaching music. Pre-service elementary teachers are prone to perceived incompetence in teaching music. Either way, failure to sing the songs good enough due to poor design of the handbook or to their own incompetency may eventually give way to not singing the songs as it should be sung in the classrooms. On the other hand, pre-service teachers may be feeling dependent on technology to learn and teach the songs because of that perceived incompetence, as well. Pre-service teachers may be needed the technology and additional materials for learning the songs by intensively listening to them because of the fact that they do not have the competence for learning the songs by reading the musical notes. Hence, they suffer considerable hardship when they cannot find the songs on the Internet or in similar easy-access sources.

Reflections on lyrics of the songs were in a more detailed language. Compared to melody and rhythm, their competency on lyrics seems to be more developed. However, pre-service teachers' opinions on the lyrics were mostly negative too. They described the lyrics as meaningless and even nonsense. Perceiving lyrics as "nonsense" may further elevate the aforementioned development of negative attitudes toward the songs. Although there were also positive opinions on the quality of the songs, they were mostly found to be simple, nonsense, insufficient and unpleasant. Participants were in accord on stressing that current handbook fails to deliver expected performance. They argued that inclusion of songs that are more appropriate for various age groups and changing conditions may contribute to the success of the music course.

Together with providing teachers with technology that supports learning and teaching songs, a THMC, which includes records of the songs and which is designed to make way for using technology, may contribute to success in music courses. For example, teachers who do not count on their own voice and do not want to sing the songs may choose to have students listen to the songs using a music player. Thus, students will hear voices with the right tone rather than hearing off-key voices. If a pre-service teacher or teacher feels incompetent in music or music education in her or his teacher-training program was insufficient, technology may be useful for preventing the development of negative attitude towards the songs, music, or music course while also helping to improve self-efficacy for making or teaching music.

\section{Recommendations}

THs are printed instructional materials, which are accessible, within easy reach, and always at teacher's elbow. As in the case of Turkey, governments may well be providing them for the teachers. Handbooks may provide guidance in times of uncertainty especially for novice teachers. In undersupplied instructional environments, THs may instantly provide teachers with clever alternative strategies, methods, techniques, and activities that they might otherwise only get to know through extensive research by investing time, money, and effort.

Teachers with overcrowded classes may use handbooks for reducing decision-making times and accelerating overall instructional process for creating time for taking care of more students or attending to more classroom situations. Teachers who are tasked with teaching a lesson that is out of their expertise may benefit from THs for being able to deliver the lessons while keeping the instruction within margin of errors. Therefore, instructional designers should design handbooks with utmost rigor.

Handbooks seem to be more noteworthy in music education considering that a significant part of music education is delivered by those who are not music teachers. Individuals' very first contact with a music course happens in 
elementary schools. In Turkey and many other countries, music course is taught by elementary teachers not only in just first year of elementary school but also in all elementary grades. Even though they get courses about music and music education in teacher training institutions, elementary teachers are not music teachers. Hence, as a teacher who are tasked with teaching music that is out of their expertise and which demands peculiar competencies, elementary teachers may benefit from a well-designed $\mathrm{TH}$.

A handbook should be designed rather than being assembled of successive facts. Textual content should be designed with message design principles in mind so that it is understandable. Images depicting the movements, objects, and exemplary gestures and overall page layout should be designed with visual communication design principles in mind so that the printed book facilities comprehension. TH is a useful educational technology facilitating learning and teaching. On the other hand, TH as well, should facilitate the use of technology by teachers and students together with the handbook while also not excluding scenarios where teachers and students have no or minimal access to technological resources. Additionally, designers should provide plentiful activities and songs appropriate for various age groups and grade levels keeping the development process of elementary student in mind. Variety and innovativeness in activities, songs, and other content items may contribute to more intensive and enthusiastic use of the TH. Moreover, a handbook should provide sufficient activities, songs, and other content which are substantial and sufficient on their own right and which are effective and influential for learning. Finally, designers should mind the cognizance of the teachers and students regarding the quality of the material that they are expected to use.

\section{References}

Al Azri, R. H., \& Al-Rashdi, M. H. (2014). The effect of using authentic materials in teaching. International journal of scientific \& technology research, 3(10), 249-254. Retrieved from http://www.ijstr.org/paper-references.php?ref=IJSTR-1014-10244

Alkar, R. (2008). İlköğretim müzik eğitimi dersinde 2007-2008 ĕgitim-öğretim yllında okutulan öğrenci çalı̧̧ma kitaplarındaki şarkıların müziksel amaçları bakımından analizi (Unpublished doctoral dissertation). Dokuz Eylul University, Izmir, Turkey. Retrieved from http://acikerisim.deu.edu.tr/xmlui/handle/12345/7348

Annand, D. (2008). Learning efficacy and cost-effectiveness of print versus e-book instructional material in an introductory financial accounting course. Journal of Interactive Online Learning, 7(2), 152-164. Retrieved from https://www.ncolr.org/issues/jiol/v7/n2/index.html

Aykaç, N. (2007). İlköğretim programinda yeralan etkinliklerin öğretmen görüşleri doğrultusunda değerlendirilmesi (Sinop ili örneği). Ahi Evran University Journal of Kirsehir Education Faculty, 8(2), 19-35. Retrieved from http://dergipark.gov.tr/aeukefd/issue/1421/17054

Ayvacı, H. Ş., \& Çoruhlu, T. Ş. (2011). İlköğretim 7. sınıf fen ve teknoloji öğretmen kılavuz kitabının öğretmen görüşlerine dayalı olarak değerlendirilmesi. Erzincan Üniversitesi Eğitim Fakültesi Dergisi, 13(1), 25-37. Retrieved from http://dergipark.gov.tr/erziefd/issue/5998/79972

Bransford, J. (2000). How people learn: Brain, mind, experience, and school. Washington, DC: National Academy Press.

Bresler, L. (1993). Music in a double-bind: Instruction by non-specialists in elementary schools. Bulletin of the Council for Research in Music Education, 115, 1-13. Retrieved from https://www.jstor.org/stable/40318744

Bulut, D. (2012). İlköğretim 8. sınıf müzik dersi öğretmen kılavuz kitabına ilişkin eleştirel bir bakış. International Journal of Human Sciences, 9(2), 109-125. Retrieved from https://www.j-humansciences.com/ojs/index.php/IJHS/article/view/2085

Bulut, D. (2014). Ortaokul 5. sınıf müzik dersi öğretmen kılavuz kitabının incelenmesi. Journal of Research in Education and Teaching, 3(3), 428-447. Retrieved from http://www.jret.org/FileUpload/ks281142/File/40.bulut.pdf

Bulut, D. (2015). Ortaokul 6. Sınıf müzik dersi öğretmen kılavuz kitabına yönelik bir değerlendirme. Journal of Research in Education and Teaching, 4(3), 246-272. Retrieved from http://www.jret.org/FileUpload/ks281142/File/28.damla_bulut.pdf

Chang, S. L., \& Ley, K. (2006). A learning strategy to compensate for cognitive overload in online learning: Learner use of printed online materials. Journal of Interactive Online Learning, 5(1), 104-117. Retrieved from https://www.learntechlib.org/p/161541/

Charmaz, K. (2006). Constructing grounded theory: A practical guide through qualitative analysis. Thousand Oaks: SAGE. 
Christensen, N. (2015, March 11). How to create an employee handbook people will actually want to read? Retrieved from https://www.fastcompany.com/3043369/5-steps-to-creating-an-employee-handbook-yourpeople-cant-wait-to-read

Creswell, J. W. (2013). Qualitative Inquiry \& Research Design: Choosing among Five Approaches (3rd ed.). Thousand Oaks: SAGE.

Demirci, B., \& Albuz, A. (2010). 2006 ilköğretim müzik dersi öğretim programına dayalı olarak hazırlanan öğretmen kılavuz ve öğrenci çalışma kitaplarının uygulamadaki görünümüne yönelik bir değerlendirme. International Journal of Human Sciences, 7(2), 247-266. Retrieved from https://www.j-humansciences.com/ojs/index.php/IJHS/article/view/1166

European Commission. (n.d.). Teacher's Handbook. London: The Mosaic Art and Sound.

Fraenkel, J. R., \& Wallen, N. E. (2000). How to design and evaluate research in education (4th ed.). Boston: McGraw-Hill.

Göçer, A., \& Aktürk, Y. (2015). İlk ve ortaokul öğretmenlerinin öğretmen kılavuz kitabına yönelik algıları: Metafor analizi. International Journal of Turkish Education Sciences, 2015(4), 186-199. Retrieved from http://dergipark.gov.tr/goputeb/issue/34518/381489

Gray, D. E. (2009). Doing research in the real world ( $2^{\text {nd }}$ ed.). London: SAGE.

Handbook. (2018). In Cambridge Dictionary. Retrieved from https://dictionary.cambridge.org/dictionary/english/handbook

Handbook. (2018). In Oxford Dictionaries. Retrieved from https://en.oxforddictionaries.com/definition/handbook

Hartley, J. (2013). Designing instructional text (3rd ed.). London: Routledge. https://doi.org/10.4324/9781315041445

Jacobson, E., Degener, S., \& Purcell-Gates, V. (2003). Creating authentic materials and activities for the adult literacy classroom: A handbook for practitioners. Boston: NCSALL. https://doi.org/10.1037/e370402004-001

Kocabaş, A. (2000). Sınıf öğretmenlerinin müzik derslerindeki yetersizliklerine ilişkin görüşleri. Pamukkale University Journal of Education, 7(7), 7-11. Retrieved from http://dergipark.gov.tr/pauefd/issue/11136/133195

Küçüköncü, Y. (2000). Sınıf öğretmenliğinde müzik eğitimi. Pamukkale University Journal of Education, 7(7), 8-12. Retrieved from http://dergipark.gov.tr/pauefd/issue/11136/133196

Maxwell, J. A. (2013). Qualitative research design: An interactive approach $\left(3^{\text {rd }}\right.$ ed.). Thousand Oaks: SAGE.

McGhee, G., Marland, G., \& Atkinson, J. (2007). Grounded theory research: Literature reviewing and reflexivity. Journal of Advanced Nursing, 60(3), 334-342. https://doi.org/10.1111/j.1365-2648.2007.04436.x

Mills, J. (1989). The generalist primary teacher of music: A problem of confidence. British Journal of Music Education, 6(2), 125-138. https://doi.org/10.1017/S0265051700007002

Ministry of National Education Textbooks and Education Tools Regulation. (2012). Official Gazette (Number: 29690). Retrieved from http://www.resmigazete.gov.tr/eskiler/2012/09/20120912-2.htm

Ministry of National Education. (2006). Illkögretim müzik dersi ögretim programı. Ankara: Devlet Kitapları Müdürlüğü.

Morineau, T., Blanche, C., Tobin, L., \& Guéguen, N. (2005). The emergence of the contextual role of the e-book in cognitive processes through an ecological and functional analysis. International Journal of Human-Computer Studies, 62(3), 329-348. https://doi.org/10.1016/j.ijhcs.2004.10.002

Özgül, İ. (2009). Müzik eğitimi ve öğretimi (6th ed.). Ankara: Pegem.

Özmenteş, S. (2009). Sınıf öğretmeni adaylarının ilköğretim müzik eğitimine ilişkin görüşleri: Antalya ilinde nitel bir araştırma. Paper presented at the Eğitimde Yeni Yönelimler Öğrenmenin Doğası ve Değerlendirme Conference, İzmir, Turkey.

Pierangeli, L. (2006). Developing a clinical teaching handbook and reference manual for part-time clinical faculty. Nurse Educator, 31(4), 183-185. https://doi.org/10.1097/00006223-200607000-00015

Prior, L. (2003). Using documents in social research. London: SAGE. https://doi.org/10.4135/9780857020222 
Rockinson-Szapkiw, A. J., Courduff, J., Carter, K., \& Bennett, D. (2013). Electronic versus traditional print textbooks: A comparison study on the influence of university students' learning. Computers \& Education, 63, 259-266. https://doi.org/10.1016/j.compedu.2012.11.022

Sağer, T (2002). Cumhuriyetten günümüze okul şarkıları üzerine bir inceleme (Unpublished doctoral dissertation). Gazi University, Ankara, Turkey.

Şahin, A. (2008). İlköğretim birinci sınıf Türkçe ders kitabı, öğrenci çalışma kitabı ve öğretmen kılavuz kitabının öğretmen görüşlerine dayalı olarak değerlendirilmesi. Ahi Evran University Journal of Kirsehir Education Faculty, 9(3), 133-146. Retrieved from http://dergipark.gov.tr/aeukefd/issue/1419/17033

Şahin, K., \& Aksüt, M. (2002). I. kademede müzik derslerine ilişkin öğretmen görüşleri. Afyon Kocatepe University Journal of Social Science, 4(2), 105-118. Retrieved from http://sbd.aku.edu.tr/?page_id=113

Spencer, C. (2006). Research on Learners' Preferences for Reading from a Printed Text or from a Computer Screen. Journal of Distance Education, 21(1), 33-50. Retrieved from http://www.ijede.ca/index.php/jde/article/view/70

Woody, W. D., Daniel, D. B., \& Baker, C. A. (2010). E-books or textbooks: Students prefer textbooks. Computers \& Education, 55(3), 945-948. https://doi.org/10.1016/j.compedu.2010.04.005

Wright, P., McCarthy, J. \& Meekison, L. (2003). Making sense of experience. In M. A. Blythe, A. F. Monk, K. Overbeeke \& P. C. Wright (Eds.), Funology: From usability to enjoyment (pp. 43-53). Dordrecht: Kluwer. https://doi.org/10.1007/1-4020-2967-5_5

Yaşar, N. (2016). İlköğretim müzik 1-2-3 öğretmen kllavuz kitabı. Ankara, Turkey: Devlet Kitapları.

Yaşar, N., Çelik, M., Şendağ, B. A. (2016). Illköğretim müzik 4-5 öğretmen kılavuz kitabı. Ankara: Devlet Kitapları.

Yünlü, F., \& Sağlam, M. (2004). Sınıf öğretmenlerinin müzik dersine ilişkin görüşleri, içerikle ilgili güçlükleri ve eğitim gereksinimleri. Journal of Educational Sciences \& Practice, 3(6), 211-226. Retrieved from http://ebuline.com/turkce/arsiv/6_5.aspx

\section{Copyrights}

Copyright for this article is retained by the author(s), with first publication rights granted to the journal.

This is an open-access article distributed under the terms and conditions of the Creative Commons Attribution license (http://creativecommons.org/licenses/by/4.0/). 